\title{
$\mathrm{PEMFC}$ 용 탄성 탄소 복합재료 분리판의 기계적 강도 및 전기전도도에 미치는 탄소섬유 필라멘트와 흑연 섬유의 영향 \\ 이재영 $\cdot$ 이우금 ${ }^{2} \cdot$ 임형렬 $^{1} \cdot$ 정규범 $^{3} \cdot$ 이홍기 $\left.\right|^{1 \dagger}$ \\ ${ }^{1}$ 우석대학교 수소연료전지 부품 및 응용기술 지역혁신센터, ${ }^{2}$ 우석대학교 신소재공학과, ${ }^{3}$ 우석대학교 전기전자공학과
}

\section{Effect of Carbon Fiber Filament and Graphite Fiber on the Mechanical Properties and Electrical Conductivity of Elastic Carbon Composite Bipolar Plate for PEMFC}

\author{
JAEYOUNG LEE ${ }^{1}$, WOOKUM LEE ${ }^{2}$, HYUNGRYUL RIMํ', GYUBUM JOUNG ${ }^{3}$, HONGKI LEE $^{1 \dagger}$ \\ ${ }^{1}$ Hydrogen Fuel Cell Parts and Applied Technology RIC, Woosuk University, Wanju, Jeonbuk 565-902, Korea \\ ${ }^{2}$ Department of Advanced Materials, Woosuk University, Wanju, Jeonbuk-do 565-701, Korea \\ ${ }^{3}$ Department of Electricity and Electrical Engineering, Woosuk University, Wanju, Jeonbuk-do 565-701, Korea
}

\begin{abstract}
Highly conductive bipolar plate for polymer electrolyte membrane fuel cell (PEMFC) was prepared using phenol novolac-type epoxy/graphite powder (GP)/carbon fiber filament (CFF) composite, and a rubber-modified epoxy resin was introduced in order to give elasticity to the bipolar plate graphite fiber (GF) was incorporated in order to improve electrical conductivity. To find out the cure condition of the mixture of novolac-type and rubber-modified epoxies, differential scanning calorimetry (DSC) was carried out and their data were introduced to Kissinger equation. And tensile and flexural tests were carried out using universal testing machine (UTM) and the surface morphology of the fractured specimen and the interfacial bonding between epoxy matrix and CFF or GF were observed by a scanning electron microscopy (SEM).
\end{abstract}

Key words : Bipolar plate(분리판), PEMFC, Graphite fiber(흑연섬유), Carbon fiber(탄소섬유), Epoxy resin(에폭 시 수지), Mechanical property(기계적 강도), Electrical conductivity(전기 전도도)

\section{1. 서 론}

고분자 전해질형 연료전지(PEMFC)는 높은 전류 밀도, 상대적으로 낮은 운전 온도, 편리한 연료 공급, 장수명 등의 장점이 있기 때문에 가정용 및 자동차 용으로 적용할 수 있는 가장 유망한 에너지원으로

\footnotetext{
${ }^{\dagger}$ Corresponding author : hongkil@woosuk.ac.kr [ 접수일 : 2014.2.26 수정일 : 2014.3.24 게재확정일 : 2014.4.30 ] Copyright (c) 2014 KHNES
}

기대되고 있다. 또한, 화석연료가 아닌 청정에너지원 인 수소를 이용하여 발전하는 시스템으로 공해물질 을 유발하지 않고, 기존의 내연기관보다 높은 발전효 율, 낮은 소음, 자유로운 이동성 등의 장점도 가지고 있다. 그러나 사용되는 재료들이 고가이면서 높은 기 술력을 요구하기 때문에 많은 연구자들과 기업들이 이와 같은 단점들을 극복하고 성능이 우수한 고분자 전해질막(PEM), 기체 확산층(GDL), 전극, 촉매, 분 리판 등을 제조하기 위해서 신소재를 개발하거나 또 
는 기존의 소재를 개량하는 연구들을 진행하고 있다 ${ }^{1-3)}$. 그 일환으로 분리판에 대한 연구가 많이 진행되고 있는데, 그 이유는 분리판의 가격이 연료전지 스택의 45 50\%를 차지하고, 그 중량의 $70 \%$ 정도를 차지하 기 때문이다 ${ }^{4-6)}$.

분리판은 연료전지 스택을 구성하는 단위 셀로부 터 생산되는 전기를 외부회로에 연결하는 전류 집전 체 역할, 효율적인 반응이 일어날 수 있도록 가스를 전극에 공급하는 역할, 생성된 물을 외부로 배출하는 역할, MEA (막전극 접합체)의 지지체 역할 및 냉각 유로를 통하여 연료전지 운전시 발생하는 열을 방출 및 회수하는 역할을 담당 한다 ${ }^{3,7-9)}$. 분리판 재료로는 내부식성 소재로 표면처리된 금속계, 도전성 금속분 말 성형품, 흑연 계, 흑연/폴리머 복합재료 등이 사용 되고 있으며, 이것들은 전기 전도도 높고, 부식 저항 성이 탁월해야 하며, 단위중량당 우수한 출력 밀도를 갖기 위해 얇게 성형될 수 있어야 한다. 금속계는 부 피/중량, 전기전도도, 열전도도, 기계적 강도 및 가스 투과도 등이 뛰어나지만, 연료전지의 격렬한 운전조 건에서 부식 문제가 앞의 장점들을 모두 상쇄시킬 만큼 심각한 문제로 작용한다. 그리고 흑연 계는 위 의 장점을 갖고 있음에도 불구하고 깨지기 쉽고, 가 격이 비싸며, 세밀하게 가스유로를 가공할 경우 기계 가공이 어렵고, 가공 공정에 많은 시간이 소요되며, 가공비가 매우 비싼 단점이 있다. 이와 같은 흑연 계 의 단점을 극복하기 위해서 흑연 분말을 폴리머에 도입한 복합재료를 사용하는 연구가 많이 진행되고 있다.

본 연구에서는 흑연/에폭시 복합재료의 내충격성 을 부여하기 위해서 노블락 타입 에폭시 수지에 탄 성에폭시를 도입하였고, 전기 전도도를 향상시키기 위해서 흑연 섬유를 도입하였다. 분리판의 전기 전도 도에 미치는 흑연화 섬유의 영향을 연구하기 위해서 4-point probe 법을 사용하였다.

\section{2. 실험방법}

\section{1 재료}

노블락 타입 에폭시 수지는 Tohto Kasei Co., Ltd. (일본)의 비스페놀-F 타입 에폭시(상품명: YSLV-80XY) 을 사용하였다. 이것의 에폭시 당량은 $190 \sim 200 \mathrm{~g} / \mathrm{eq}$ 이 고, 녹는점은 $78^{\circ} \mathrm{C}$ 이며, 용융 점도는 $150^{\circ} \mathrm{C}$ 에서 $0.1 \mathrm{~Pa} \cdot \mathrm{S}$ 이다. 탄성 에폭시는 국도화학의 KR-170을 사용하였 다. 이것의 에폭시 당량은 $200 ~ 235 \mathrm{~g} / \mathrm{eq}$ 이고, carboxyl terminated butadiene acrylonitrile (CTBN)으로 변성 되었다. 페놀 노블락 타입 경화제는 수산기 당량이 $104 \mathrm{~g} / \mathrm{eq}$ 이고, 연화점이 $105^{\circ} \mathrm{C}$ 인 강남화성의 $\mathrm{KPN} 2110$ 을 사용하였다. 그리고 촉매는 triphenyl phosphine, $\mathrm{TPP}$ 을 사용하였다. 흑연 분말은 TIMCAL사(스위스) 의 TIMREX SFG6L 제품을 사용하였다. 이것의 탄

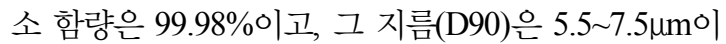
었다. 탄소섬유는 Toray 사(일본)의 T700SC-24000-50C 를 $1 \mathrm{~cm}$ 길이로 잘라서 사용하였고, 그 필라멘트의 지 름은 $7 \mu \mathrm{m}$ 이었으며, 흑연 섬유는 Kureha Chemical 사 의 KGF-200를 사용하였고, 그 길이가 $3 \mathrm{~mm}$ 이고, 지 름이 $14.5 \mu \mathrm{m}$ 이었다.

\section{2 가열 압축성형에 의한 시편 제조}

에폭시/흑연 분말/탄소섬유 필라멘트/흑연 섬유 복 합재료를 가열 압축성형하는 절차는 다음과 같다. 먼 저, 에폭시 수지 중에 혼합된 탄소 재료들이 에폭시 수지의 경화반응 속도에 어떤 영향도 미치지 않기 때문에 경화반응 조건은 탄소재료가 포함되지 않은 에폭시 수지 계를 이용하여 분석하였다. 노볼락 타입 에폭시 수지 $(8 \mathrm{~g})$ 와 탄성 에폭시 수지 $(2 \mathrm{~g})$ 을 당량비의 경화제 $(12.8 \mathrm{~g})$ 과 혼합하고, 반응을 촉진하기 위해서 촉매 $(0.1 \mathrm{~g})$ 을 혼합 믹서를 사용하여 분말상으로 균질 하게 혼합하였다. 경화반응 속도를 구하기 위해서 시 
차 주사 열량 분석(DSC Infinity, Instrument Specialists, Inc., USA)을 행하였다. DSC용 알루미늄(Al) 팬에 에 폭시/탄소 분말 혼합물을 7 10mg을 넣은 후 DSC 셀 에 넣고, 실온에서 $300^{\circ} \mathrm{C}$ 까지 승온속도를 $5,10,15$ 및 $20^{\circ} \mathrm{C} / \mathrm{min}$ 의 조건에서 각각 $\mathrm{DSC}$ 분석을 행하였고, 그 결과를 아래의 Kissinger equation ${ }^{10)}$ 에 대입하여 열경화 반응 활성화 에너지 및 pre-exponential factor 값을 구하였다.

$$
-\ln \left(q / T_{P}^{2}\right)=E_{a} / R T_{P}-\ln \left(A R / E_{a}\right)
$$

여기서 $q$ : 승온속도, $T_{P}$ : 발열피크가 나타나는 온도, $E_{a}$ : 경화반응 활성화 에너지, $A$ : pre-exponential factor, 그리고 $R$ : 기체상수, $8.314 \mathrm{~J} / \mathrm{mol} \cdot \mathrm{K}$ 이다. 이 연구를 통 해서 본 에폭시 계의 경화반응 온도 및 시간은 $120^{\circ} \mathrm{C}$ 에서 2시간 경화반응 후 연속적으로 $180^{\circ} \mathrm{C}$ 에서 3 시 간 동안 후경화를 시키는 것이 최적반응임을 알 수 있었고, 이 조건에 따라 분리판을 가열 압축 성형하 였다.

에폭시/탄소 복합재료 계의 기계적 특성을 분석하 기 위해서 에폭시 매트릭스 $25 \mathrm{wt} \%$ 에 흑연 입자 $65-70 \mathrm{wt} \%$ 와 흑연 섬유 $1 \sim 5 \mathrm{wt} \%$, 그리고 탄소섬유 필라멘트를 $1 \sim 5 \mathrm{wt} \%$ 등을 변화시키면서 혼합하였다. 모든 원료 들이 분말상 또는 섬유상이기 때문에 혼합 믹서를 사 용하여 고르게 분산시킨 후 사용하였다. 에폭시/탄소 복합재료의 조성물 혼합비는 $\mathrm{E}_{\mathrm{a}}-\mathrm{GP}_{\mathrm{b}}-\mathrm{CFF}_{\mathrm{c}}-\mathrm{GF}_{\mathrm{d}}$ 으로 명명하였고, 여기서 $\mathrm{E}$ 는 에폭시 매트릭스, $\mathrm{GP}$ 는 흑 연 입자(graphite powder), $\mathrm{CFF}$ 는 탄소섬유 필라멘트 (carbon fiber filament), 그리고 $\mathrm{GF}$ 는 흑연 섬유(graphite fiber)를 뜻하며, 아래 첨자 $\mathrm{a}, \mathrm{b}, \mathrm{c}, \mathrm{d}$ 는 각 성분의 중 량 조성비를 나타낸다.

\section{3 기기분석}

각각의 조성비를 갖는 에폭시/탄소 복합재료에 대 해서 두께 $2.5 \mathrm{~mm}$ 의 시험편을 제조한 후 인장시험 및
굴곡시험을 행하였다. 인장시편은 JIS B7502에 의해 제작되었고, 만능 시험기(SHM-C-500, Shamhan Tech, 한국)을 사용하여 $50 \mathrm{~mm} / \mathrm{min}$ 의 crosshead 속도로 측 정하였다. 굴곡시편은 JIS B7507에 의해 $70 \mathrm{~mm} \times 10$ $\mathrm{mm} \times 2.5 \mathrm{~mm}$ 크기의 시편을 제작하였고, 3 점 굴곡 시험법에 의해 굴곡강도를 측정하였다. 이 시험도 인 장시험에서 사용한 것과 같은 만능 시험기를 사용하 여 측정하였고, crosshead 속도도는 $50 \mathrm{~mm} / \mathrm{min}$ 이었다. 두 시험의 측정온도는 $23^{\circ} \mathrm{C}$ 이고, 상대습도는 $50 \%$ 이 었다.

탄소 섬유 필라멘트 또는 흑연 섬유와 에폭시 수 지의 결합상태를 관찰하기 위해서 인장시험 파단면을 전계 방사형 주사 전자현미경(FE-SEM, JMS-6701F, $\mathrm{JEOL})$ 을 사용하여 관찰하였다. 이 때 가속 전압은 $15 \mathrm{kV}$ 이었다.

\section{3. 결과 및 고찰}

경화반응 속도론을 연구하기 위해서 노블락 에폭 시/탄성에폭시/경화제/촉매 혼합분말을 사용하여 승 온속도 $5,10,15$ 그리고 $20^{\circ} \mathrm{C} / \mathrm{min}$ 의 조건에서 각각 $\mathrm{DSC}$ 분석을 행하였고, 그 결과를 Fig. 1에 나타내었

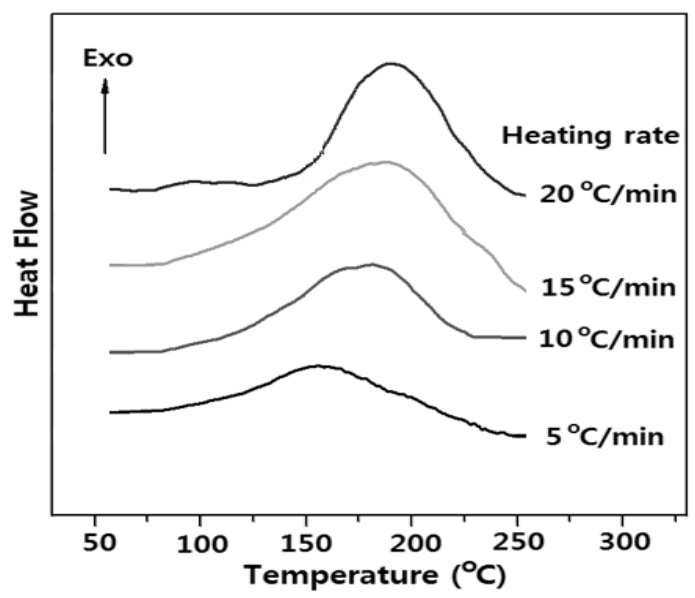

Fig. 1 DSC curves for novolac epoxy (8g)/elastic epoxy (2g)/ curing agent $(12.8 \mathrm{~g}) /$ catalyst $(0.1 \mathrm{~g})$ system at various curves 
다. 승온속도가 $10^{\circ} \mathrm{C} / \mathrm{min}$ 인 thermogram에서 경화반응 에 의한 발열반응은 $100^{\circ} \mathrm{C}$ 정도에서 시작되어 $188.2^{\circ} \mathrm{C}$ 에서 최대 발열피크 값을 보인 후 발열량이 감소하는 것을 볼 수 있다. 승온속도가 증가함에 따라 발열 피 크에서의 온도가 증가하는 것을 알 수 있으며, 이는 승온속도가 증가함에 따라 짧은 시간 동안에 경화반 응이 진행되기 때문에 그 발열량이 증가하였기 때문 이다. 각각의 승온속도에서의 발열피크 온도를 구하 여 Table 1에 나타내었고, Kissinger equation에 의해 열경화 반응 활성화 에너지 및 pre-exponential factor 를 구하기 위해서 $-\ln \left(\mathrm{q} / \mathrm{T}_{\mathrm{P}}^{2}\right)$ 항과 $1 / \mathrm{T}_{\mathrm{p}}$ 항을 구하여 Table 1에 같이 나타내었다. 이 두 항의 직선의 관계 식을 구하기 위해서 Fig. 2에서와 같이 least squares fitting 법을 사용하여 식(2)와 같은 직선의 관계식을 구하였다.

$$
-\ln \left(q / T_{P}^{2}\right)=15.89 \times 10^{3} / T_{P}-32.85
$$

Table 1 Cure kinetic parameters for Figure 1

\begin{tabular}{c|c|c|c}
\hline \hline $\mathrm{q}(\mathrm{K} / \mathrm{min})$ & $\mathrm{T}_{\mathrm{P}}(\mathrm{K})$ & $1 / \mathrm{T}_{\mathrm{P}} \times 10^{3}\left(\mathrm{~K}^{-1}\right)$ & $-\ln \left(\mathrm{q} / \mathrm{T}_{\mathrm{P}}{ }^{2}\right)$ \\
\hline 5 & 452.5 & 2.21 & 10.62 \\
\hline 10 & 461.3 & 2.17 & 9.96 \\
\hline 15 & 467.5 & 2.14 & 9.59 \\
\hline 20 & 470.9 & 2.12 & 9.31 \\
\hline
\end{tabular}

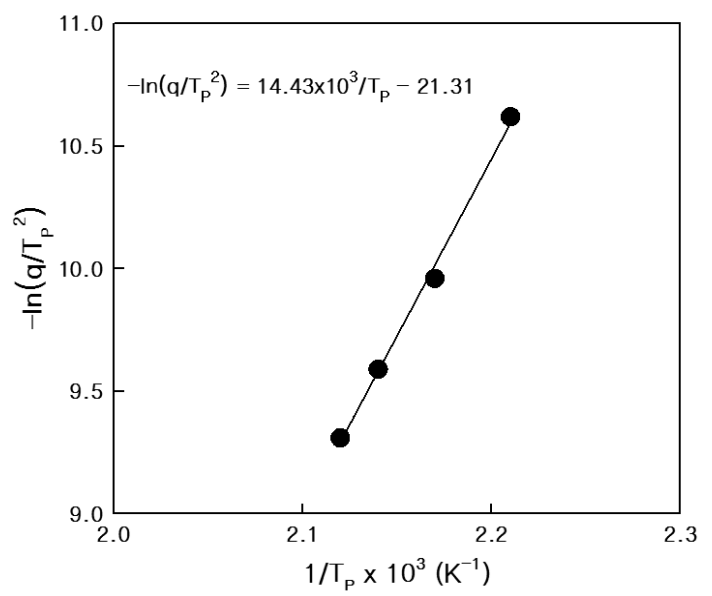

Fig. 2 Kissinger plot of $1 / T_{p}$ vs. $-\ln \left(q / T_{p}{ }^{2}\right)$ for novolac epoxy $(8 \mathrm{~g}) /$ elastic epoxy $(2 \mathrm{~g}) /$ curing agent $(12.8 \mathrm{~g}) /$ catalyst $(0.1 \mathrm{~g})$ system
이 직선의 기울기로부터 경화반응 활성화 에너지를 구할 수 있고, $\mathrm{y}$-절편으로부터 pre-exponential factor 를 구할 수 있다. 이 값들은 각각 $123.8 \mathrm{~kJ} / \mathrm{mol}$ 과 1.28 $\times 10^{12} \mathrm{~min}^{-1}$ 이었다. 이것으로부터 본 에폭시 계의 경 화반응 온도 및 시간은 $120^{\circ} \mathrm{C}$ 에서 2시간 경화반응 후 연속적으로 $180^{\circ} \mathrm{C}$ 에서 3 시간 동안 후경화를 시키 는 것이 최적반응임을 알 수 있었다.

Fig. 3 는 에폭시/탄소 복합재료의 인장강도에 미치 는 탄소섬유 필라멘트의 영향을 나타내었다. 에폭시 $/ \mathrm{GP}$ 계의 인장강도는 $22.7 \mathrm{MPa}$ 이고, $\mathrm{CFF}$ 함량이 증 가함에 따라 인장강도가 증가하였다. $\mathrm{CFF}$ 가 $3 \mathrm{wt} \%$ 첨가된 계는 $143 \%$ 증가된 값을 나타내었다.

에폭시/탄소 복합재료의 굴곡강도에 미치는 $\mathrm{CFF}$ 함량의 영향(Fig. 4)에 대해서도 평가하였으며, 인장 강도에서와 마찬가지로 $\mathrm{CFF}$ 함량이 증가함에 따라 굴곡강도가 증가하였다. 에폭시/GP 계의 굴곡강도는 $52.4 \mathrm{MPa}$ 이고, $\mathrm{CFF}$ 가 $3 \mathrm{wt} \%$ 첨가된 계는 $138 \%$ 증가된 값을 나타내었다. 이는 $\mathrm{CFF}$ 가 에폭시 복합재료 내에 서 강한 결합력을 발휘하면서 기계적 특성을 강화시 키기 때문이다. 에폭시와 CFF 사이의 강한 결합력을 관찰하기 위해서 인장 시편 파단면을 SEM으로 관찰 하여 Fig. 5에 나타내었다. CFF가 첨가되지 않은 계

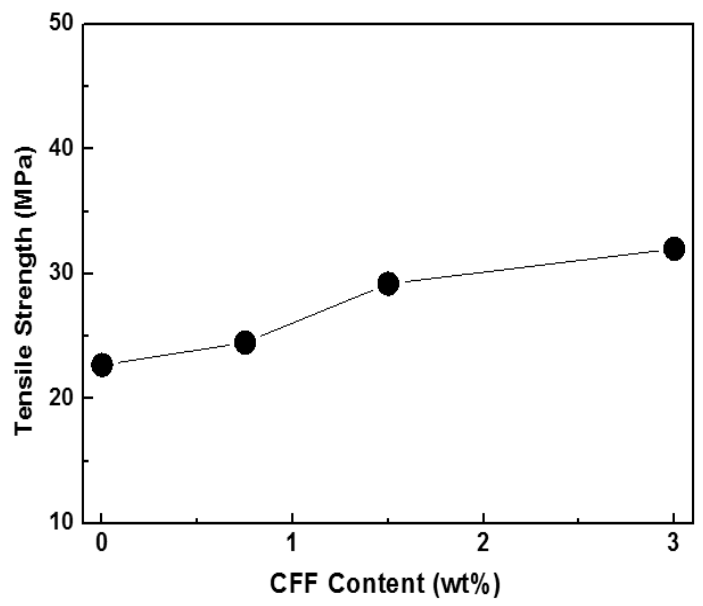

Fig. 3 Effect of CFF content on the tensile strength of $\mathrm{E}_{25}-\mathrm{GP}_{\mathrm{b}}-\mathrm{CFF}_{\mathrm{c}}$ composite, where $\mathrm{b}+\mathrm{c}=75$ 


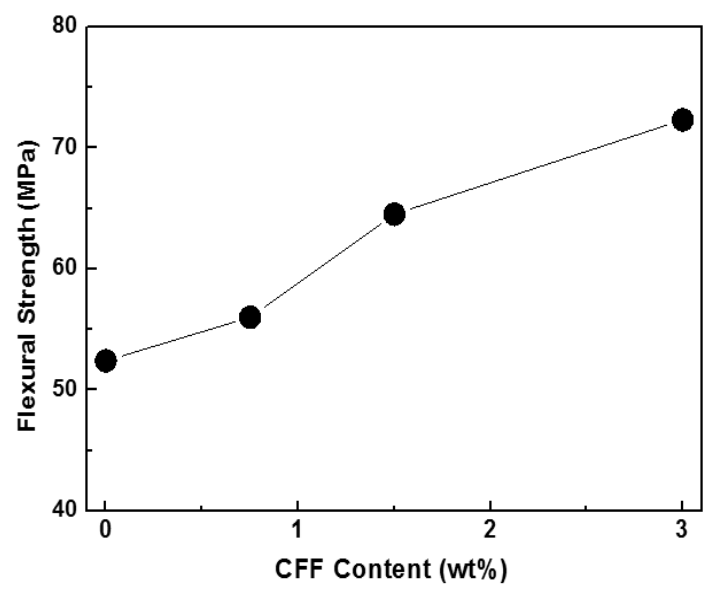

Fig. 4 Effect of CFF content on the flexural strength of $\mathrm{E}_{25}-\mathrm{GP}_{\mathrm{b}}-\mathrm{CFF}_{\mathrm{c}}$ composite, where $\mathrm{b}+\mathrm{c}=75$

에 대한 SEM 관찰 결과를 Fig. 5(A)에 나타내었고, 입자상 흑연이 균일하게 분산되어 있으며 거시적으 로 입자들이 서로 연결되어 있는 것을 볼 수 있다. 그 리고, $\mathrm{CFF}$ 가 $3 \mathrm{wt} \%$ 첨가된 계에서 $\mathrm{CFF}$ 의 분산 상태 를 확인하기 위해 Fig. 5(B)에서와 같이 저배율로 파 단면을 관찰하였고, 첨가된 $\mathrm{CFF}$ 가 전체적으로 균일 하게 분산되어 있고, 이것들이 에폭시 매트릭스로부 터 빠져나온 것들을 볼 수 있다. 에폭시와 CFF 사이 의 계면 강도를 평가하기 위해서 에폭시 매트릭스로 부터 빠져나온 CFF 표면을 고배율로 관찰하였고, 그 사진을 Fig. 5(C)에 나타내었다. 사진에서 보듯이 CFF 표면이 에폭시 수지로 완전히 코팅되어 있는 것을 볼 수 있는데, 이것은 Fig. 5(C)에 삽입된 신품 $\mathrm{CFF}$ 표 면 사진이 매끈하고 두께가 약간 얇은 것과 대조적 이다. 이는 $\mathrm{CFF}$ 와 에폭시 사이에 강한 결합력이 작 용하기 때문에 파단에 의해서 CFF가 에폭시 매트릭 스로부터 빠져 나올 때 다량의 에폭시가 부착된 상 태로 빠져나오기 때문이다. 즉, 에폭시 매트릭스와 섬유상 보강재 사이의 강한 파괴에너지는 debonding energy, post debond friction energy 그리고 pull-out energy 메커니즘으로 설명할 수 있다 ${ }^{11-13)}$. 섬유가 매 트릭스 내에서 절단되는 과정에서 소비되는 에너지 를 debonding energy라 하고, 절단된 섬유 주변에서
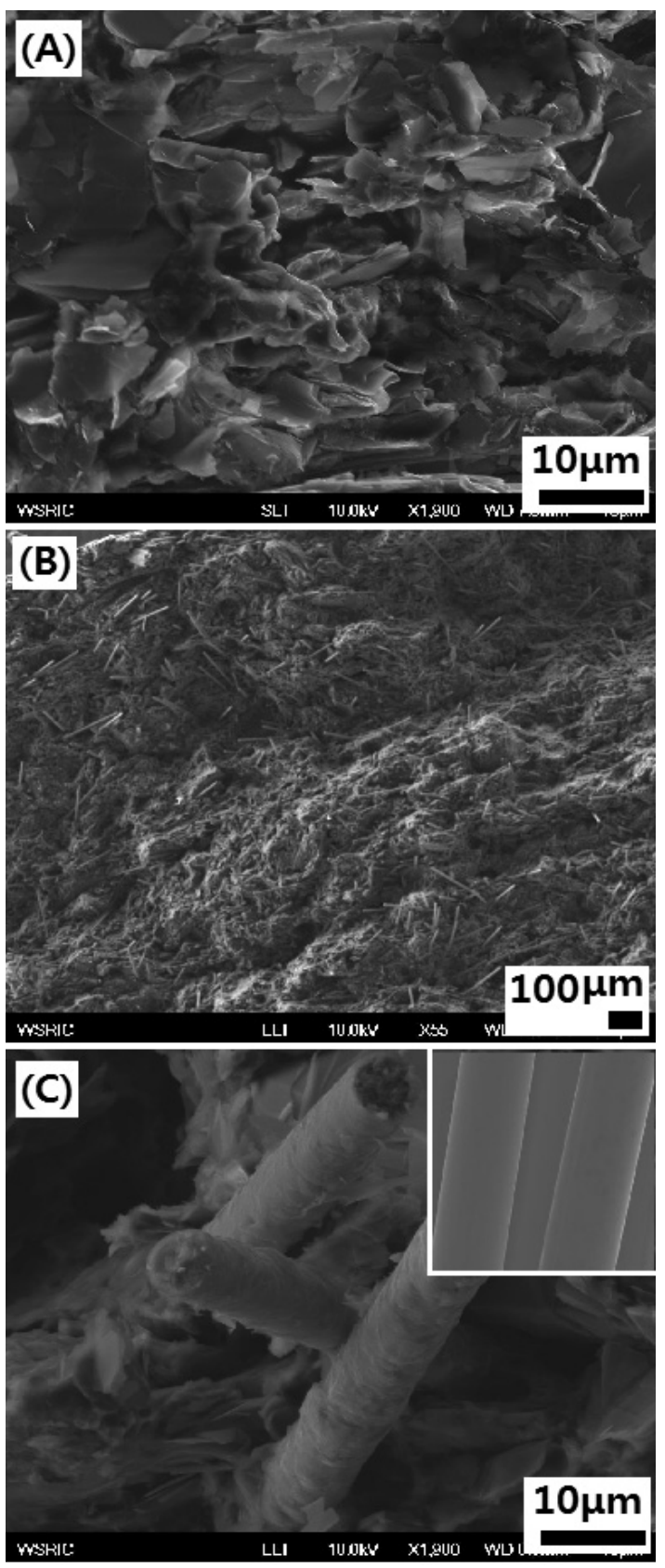

Fig. 5 SEM photos for the fracture surface of $(A) E_{25}$ $\mathrm{GP}_{75}-\mathrm{CFF}_{0}$ and (B) $\mathrm{E}_{25}-\mathrm{GP}_{72}-\mathrm{CFF}_{3}$ systems. (C) shows the pulled-out CFF surface in (B) and the inset was for new CFF

섬유와 고분자 매트릭스의 계면이 분리되면서 소비 되는 post debond friction energy, 그리고 섬유가 고 분자 매트릭스로부터 빠져나오는 과정에서 소비되는 
pull-out energy를 구성되어 있다는 것이다. 따라서 섬유상 표면에 고분자 매트릭스가 다량 부착되어 있 다는 것은 그것들 사이의 계면 강도가 크기 때문에 post debond friction energy가 높게 작용하므로 기계 적 강도가 증가하게 되는 것이다.

Fig. 6은 에폭시/탄소 복합재료의 전기 전도도에 미치는 CFF 함량의 영향을 나타내었다. 에폭시/GP 계의 전기 전도도는 $27.6 \mathrm{~S} / \mathrm{cm}$ 이고, $\mathrm{CFF}$ 함량이 증가함 에 따라 감소하였다. $\mathrm{CFF}$ 가 $3 \mathrm{wt} \%$ 첨가된 계는 $23.8 \mathrm{~S} / \mathrm{cm}$ 으로 $86.2 \%$ 감소된 값을 나타내었다. 이는 $\mathrm{CFF}$ 가 흑 연 입자 간에 연결 통로가 되어 전자의 이동 통로로 작용할 것으로 예상했으나, 탄소섬유 중에 국부적으 로 비결정성 영역이 존재하기 때문에 전도도가 낮아 진 것으로 판단된다. 따라서 분리판의 가장 중요한 충족 요소인 전기 전도도를 향상시키기 위해서는 결 정화도가 높은 흑연 섬유를 도입할 필요가 있다.

Fig. 7은 에폭시/탄소 복합재료의 전기 전도도에 미 치는 $\mathrm{GF}$ 함량의 영향을 나타내었다. GF 함량이 증가 함에 따라 전기 전도도가 증가하였고, $\mathrm{GF}$ 함량이 가장 높은 $\mathrm{E}_{25}-\mathrm{GP}_{65}-\mathrm{CFF}_{2}-\mathrm{GF}_{8}$ 계의 전기전도도는 $88.6 \mathrm{~S} / \mathrm{cm}$ 이었다. 이 값은 $\mathrm{GF}$ 가 첨가되지 않은 $\mathrm{E}_{25}-\mathrm{GP}_{73}-\mathrm{CFF}_{2-}$ $\mathrm{GF}_{0}$ 의 $25.2 \mathrm{~S} / \mathrm{cm}$ 에 비해 3.5 배 향상된 값이다. 이는

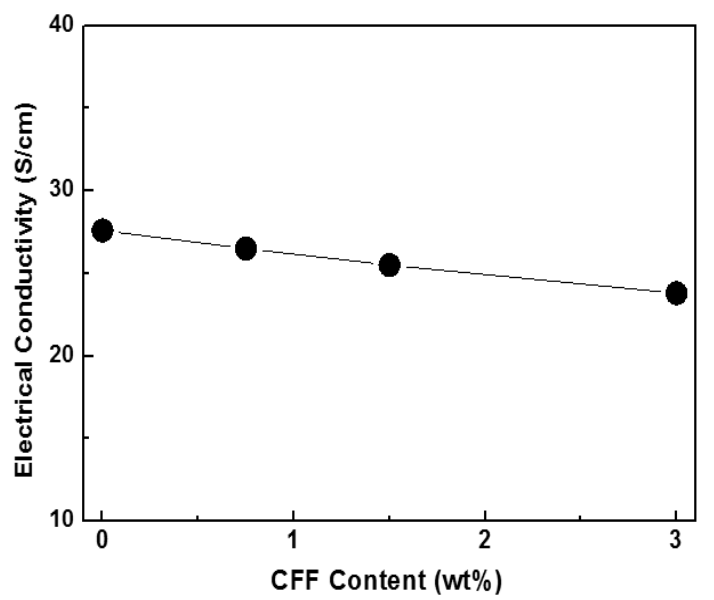

Fig. 6 Effect of CFF content on the electrical conductivity of $\mathrm{E}_{25}-\mathrm{GP}_{\mathrm{b}}-\mathrm{CFF}_{\mathrm{c}}$ composite, where $\mathrm{b}+\mathrm{c}=75$
흑연 섬유가 멀리 떨어져 있는 흑연 입자 간에 전자 의 이동 통로로 작용하기 때문이다. GF함량이 에폭 시/탄소 복합재료의 기계적 강도에 미치는 영향은 본 논문에서 그림으로 나타내지는 않았지만 $\mathrm{GF}$ 함량에 비례해서 증가하는 것을 볼 수 있었다. 이는 GF의 인 장강도 및 굴곡강도가 $\mathrm{CFF}$ 와 거의 비슷한 값을 갖기 때문이다. $\mathrm{GF}$ 함량이 $8 \mathrm{wt} \%$ 인 $\mathrm{E}_{25}-\mathrm{GP}_{65}-\mathrm{CFF}_{2}-\mathrm{GF}_{8}$ 계 의 인장강도는 $43.0 \mathrm{MPa}$ 이고, 굴곡강도는 $73.4 \mathrm{MPa}$ 이 었다.

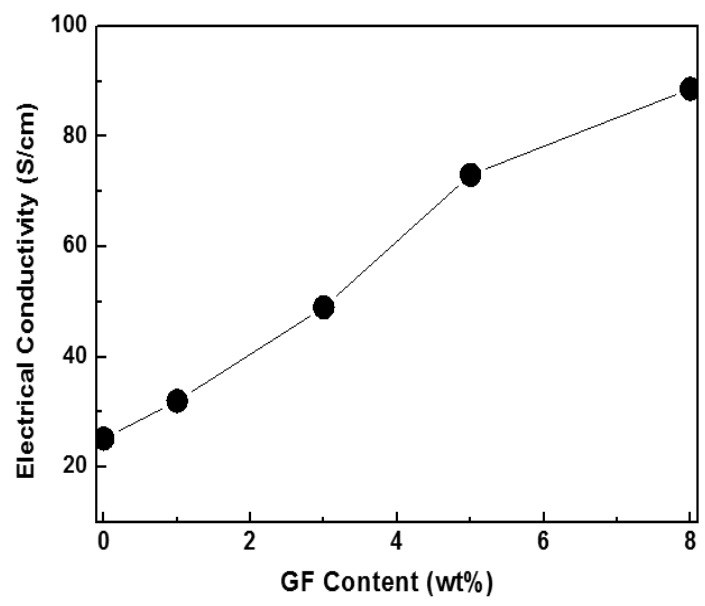

Fig. 7 Effect of GF content on the electrical conductivity of $\mathrm{E}_{25}-\mathrm{GP}_{\mathrm{b}}-\mathrm{CFF}_{2}-\mathrm{GF}_{\mathrm{d}}$ composite, where $\mathrm{b}+\mathrm{d}=73$

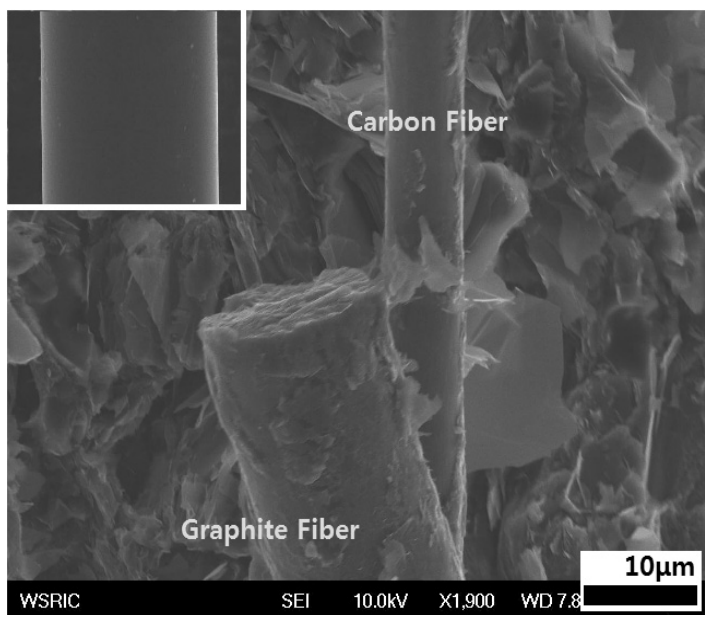

Fig. 8 SEM photo for the pulled-out GF surface in $E_{25}$ $\mathrm{GP}_{70}-\mathrm{CFF}_{2}-\mathrm{GF}_{3}$. The inset was for new GF 
미국 에너지성(DOE)의 2015년도 전기전도도 목 표값은 $100 \mathrm{~S} / \mathrm{cm}$ 이상이고, 굴곡강도 목표값은 $25 \mathrm{MPa}$ 이상이다. 본 연구의 $\mathrm{E}_{25}-\mathrm{GP}_{65}-\mathrm{CFF}_{2}-\mathrm{GF}_{8}$ 계 굴곡강도 는 $73.4 \mathrm{MPa}$ 로 $\mathrm{DOE}$ 목표값을 크게 상회하였고, 전기 전도도는 $88.6 \mathrm{~S} / \mathrm{cm}$ 로 약간 미치지 못하였다. 그렇지 만 이 값도 $\mathrm{GF}$ 함량을 $10 \mathrm{wt} \%$ 정도로 증가시키면 충 분히 달성될 수 있을 것으로 판단된다.

\section{4. 결 론}

PEMFC용 분리판 제작을 위해 노블락 에폭시/탄 성에폭시/탄소 복합재료 계가 사용되었다. 노볼락 타 입 에폭시 수지(8g)/탄성 에폭시 수지(2g)/경화제(12.8g)/ 촉매 $(0.1 \mathrm{~g})$ 계의 경화반응 활성화 에너지는 $123.8 \mathrm{~kJ} / \mathrm{mol}$ 이고, pre-exponential factor 값은 $1.28 \times 10^{12} \mathrm{~min}^{-1}$ 이 었다. 에폭시 $/ \mathrm{GP} / \mathrm{CFF}$ 계에서 $\mathrm{CFF}$ 의 함량이 증가함 에 따라 인장강도 및 굴곡강도가 증가하였고, $\mathrm{CFF}$ 가 $3 \mathrm{wt} \%$ 첨가되었을 때 이 값들이 $140 \%$ 정도 증가하였 다. 이것은 에폭시와 $\mathrm{CFF}$ 사이에 강한 결합력이 작 용하므로 인해 파괴 에너지가 크게 증가하였기 때문 이다. 그렇지만 $\mathrm{CFF}$ 는 전기 전도도에 악영향을 미치 는 것이 확인되었으며, 이 값을 향상시키기 위해서 흑연 섬유를 도입하였다. 에폭시 $/ \mathrm{GP} / \mathrm{CFF} / \mathrm{GF}$ 계에서 $\mathrm{GF}$ 함량이 증가함에 따라 전기 전도도가 증가하였 고, $\mathrm{GF}$ 함량이 가장 높은 $\mathrm{E}_{25}-\mathrm{GP}_{65}-\mathrm{CFF}_{2}-\mathrm{GF}_{8}$ 계의 전 기전도도는 $88.6 \mathrm{~S} / \mathrm{cm}$ 으로 $\mathrm{GF}$ 가 첨가되지 않은 $\mathrm{E}_{25}$ $\mathrm{GP}_{73}-\mathrm{CFF}_{2}-\mathrm{GF}_{0}$ 계의 $25.2 \mathrm{~S} / \mathrm{cm}$ 에 비해 3.5 배 향상된 값을 나타내었다.

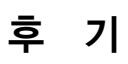

본 연구는 교육부와 한국연구재단의 지역혁신인 력양성사업으로 수행된 연구결과임(한국연구재단 No. 2013032228). 또한 본 연구는 산업통상자원부 지역 혁신센터사업(2014)으로 수행된 연구결과임.

\section{References}

1. F. A. de Bruijn, V. A. T. Dam1, and G. J. M. Janssen, "Review: Durability and Degradation Issues of PEM Fuel Cell Components", Fuel Cells, Vol.8, No. 1, 2008, p. 3.

2. A. Garsuch, D. A. Stevens, R. J. Sanderson, S. Wang, R. T. Atanasoski, S. Hendricks, M. K. Debe, and J. R. Dahna, "Alternative Catalyst Supports Deposited on Nanostructured Thin Films for Proton Exchange Membrane Fuel Cells", J. Electrochem. Soc. Vol. 157, No.2, 2010, p. B187.

3. S. R. Dhakate, R. B. Mathur, B. K. Kakati, and T. L. Dhami, "Properties of graphite-composite bipolar plate prepared by compression molding technique for PEM fuel cell", International Journal of Hydrogen Energy, Vol. 32, No.17, 2007, p. 4537.

4. S. R. Dhakatea, S. Sharma, and R. B. Mathura, "A Low-Density Graphite-Polymer Composite as a Bipolar Plate for Proton Exchange Membrane Fuel Cells", Carbon Letters, Vol. 14, No. 1, 2013, p. 40.

5. H. Tsuchiya, and O. Kobayashi, "Mass Production Cost of PEM Fuel Cell by Learning Curve", International Journal of Hydrogen Energy, Vol. 29, No.10, 2004, p. 985.

6. J. Laminie, and A. Dicks, "Fuel Cell Systems Explained”, Wiley, New York, 2000.

7. B. K. Kakati, and D. Deka, "Differences in physicomechanical behaviors of resol(e) and novolac type phenolic resin based composite bipolar plate for proton exchange membrane (PEM) fuel cell", Electrochimica Acta, Vol. 52, No. 25, 2007, p. 7330.

8. S. Srinivasan, "Fuel Cells for Extraterrestrial and Terrestrial Applications", J. Electrochem. Soc., Vol. 136, No.2, 1989, 41c.

9. S. J. Lee, S. Mukherjee, J. McBreen, Y. W. Rho, Y. T. Kho, and T. H. Lee, "Effects of Nafion impregnation on performances of PEMFC electrodes", 
$138 \mathrm{PEMFC}$ 용 탄성 탄소 복합재료 분리판의 기계적 강도 및 전기전도도에 미치는 탄소섬유 필라멘트와 흑연 섬유의 영향

Electrochim. Acta, Vol. 43, No. 24, 1998, p. 3693.

10. R. B. Prime, "Thermal Characterization of Polymeric Materials", Academic Press, New York, 1982, p. 435.

11. B. Gershon, and G. Marom, "Fracture toughness and mechanical properties of glass fibre-epoxy composites", J. Mater. Sci., Vol. 10, No. 9, 1975, p. 1549.
12. J. N. Kirk, M. Munro, and P. W. R. Beaumont, "The fracture energy of hybrid carbon and glass fibre composites", J. Mater. Sci., Vol. 13, No. 10, 1978, p. 2197.

13. P. W. R. Beaumont, and P. D. Anstice, "A failure analysis of the micromechanisms of fracture of carbon fibre and glass fibre composites in monotonic loading", J. Mater. Sci., Vol.15, No. 10, 1980, p. 2619. 